\title{
Perlindungan Hutan Ulayat Masyarakat Hukum Adat Sawai dari Kegiatan Usaha Pertambangan
}

\section{Olvin Hady}

Olvin Hady; Fakultas Hukum Universitas Brawijaya; Jalan Veteran; Malang; 65145; Indonesia.

\begin{abstract}
ARTICLEINFO
Article history:

Received 2018-04-29

Received in revised form

2018-05-02

Accepted 2018-06-01

Kata kunci:

Perlindungan, Hutan Ulayat, Masyarakat Hukum Adat.

Keywords:

Protection, Ulayat Forest, Society

of Adat Law

Abstrak

Penelitian ini bertujuan untuk memahami dan menganalisis apakah ada ketidaksesuaian dengan Hukum Nasional dalam penolakan Masyarakat Hukum Adat Sawai untuk melindungi Hutan Ulayat masyarakat dari kegiatan usaha pertambangan PT. WBN serta bagaimana penyelesaian sengketa antara Masyarakat Hukum Adat Sawai dengan PT. WBN sebagai bentuk perlindungan hukum. Tipe penelitian yang digunakan adalah yuridis empiris, menggunakan pendekatan yuridis-sosiologis. Prosedur pengumpulan bahanhukum melalui studi kepustakaan serta menggunakan teknik analisis bahan hukum dengan metode deskriptif kualitatif.Hasil penelitian ini menunjukkan bahwa Perlawanan Masyarakat Hukum Adat Sawai ada yang bertentangan dengan Hukum Nasional dan ada juga yang sesuai dengan Hukum Nasional Penyelesaian sengketa antara PT. WBN dengan Masyarakat Hukum Adat Sawai juga belum menemui titik terang. Hal ini disebabkan oleh perbedaan harga ganti rugi pembebasan lahan yang dirasa tidak sesuai dengan permintaan Masyarakat Hukum Adat Sawai serta kecendrungan Pemerintah Kabupaten Halmahera Tengah yang lebih menunjukan keberpihakan kepada PT. WBN.
\end{abstract}

\begin{abstract}
This research is aimed to understand and analysis about the incompatibility of national law in the rejection from customary law community of sawai in order to protect the ulayat forest from the mining business activities of PT.WBN. Also this research aimed to give a solution about how to solve the conflict between customary law community of sawai with PT. WBN as a form of legal protection. The type of this research is empirical juridical with juridical sociology approach. The procedure to collect the data is use library research as the technique to analysis and also used the technique analysis of legal material with descriptive qualitative as the method. The result of this research is to show The resistance of law community of sawai is contrary
\end{abstract}

Corresponding Author:

Olvin Hady

E-mail address: olvin_hady@yahoo.com

DOI: https://doi.org/10.26905/idjch.v9i1.2113 


\section{Perlindungan Hutan Ulayat Masyarakat Hukum Adat Sawai dari Kegiatan Usaha Pertambangan}

Olvin Hady

with national law. The right forest is the forest area of customary law community. The Settlement of the conflict from PT.WBN with customary law community not already find a solution to solve the problem. It is because there is a differences between the price of land acquisition which is unappropriated with the demand of customary law community of sawai. And also there is tendencies from the district government of Halmahera Tengah which is more partiality with PT.WBN.

\section{Latar Belakang}

Hutan Ulayat merupakan salah satu jenis hutan yang ada di Indonesia yang termasuk dalam Hutan Hak karena merupakan Hak Ulayat Masyarakat Hukum Adat. Dalam Undang-Undang Dasar Negara Republik Indonesia Tahun 1945, disebutkan bahwa keberadaan Masyarakat Hukum Adat diakui beserta hak-hak tradisonalnya, oleh sebab itu, keberadaan Masyarakat Hukum Adat diakui secara konstitusional di Negara Kesatuan Republik Indonesia. Secara konstitusional pengakuan ini diatur dalam Pasal 18B Ayat 2 yang menyatakan bahwa:

"Negara mengakui dan menghormati kesatuan-kesatuan masyarakat Hukum Adat beserta hak-hak tradisonalnya sepanjang masih hidup dan sesuai dengan perkembangan masyarakat dan prinsip Negara Kesatuan Republik Indonesia, yang diatur dalamm Undang-Undang".

Masyarakat Hukum Adat yang menjadi subjek dari Hak Ulayat mendiami suatu wilayah tertentu, dan hutan merupakan salah satu sumber kehidupannya yang merupakan objek dari Hak Ulayat. Hutan yang merupakan objek dari Hak Ulayat di kenal sebagai Hutan Ulayat. Hutan Ulayat merupakan hutan yang berada dalam teritori Masyarakat Hukum Adat, menurut Maria SW Soemardjono (2007), Hak Ulayat merupakan hak yang melekat sebagai kompetisi yang menjadi se- suatu yang khas pada Masyarakat Hukum Adat, berupa wewenang, kekuasaan mengurus dan mengatur tanah dan seisinya dengan daya laku ke dalam maupun keluar.

Pengakuan terhadap Hak-Hak Ulayat Masyarakat Hukum Adat juga diatur dalam Pasal 3 Undang-Undang Nomor 5 Tahun 1960 tentang Peraturan Dasar-Dasar Pokok Agraria (lebih lanjut disingkat UUPA) yang menyatakan bahwa:

"Dengan mengingat ketentuan Pasal 1 dan 2 pelaksanaan hak ulayat dan hak-hak yang serupa itu dari masyarakat-masyarakat hukum adat, sepanjang menurut kenyataannya masih ada, harus sedemikian rupa sehingga sesuai dengan kepentingan nasional dan Negara, yang berdasarkan atas persatuan bangsa serta tidak bolehbertentangan denganundang-undang atau peraturan-peraturan lain yang lebih tinggi".

Seiring dengan pentingnya peran Hutan Ulayat dalam kehidupan masyarakat terutama Masyarakat Hukum Adat, maka hutan ulayat sering menjadi objek yang bisa menimbulkan sengketa antara Masyarakat Hukum Adat dengan pihak yang melakukan ekploitasi terhadap Hutan Ulayat. Beberapa tipologi konflik yang menyangkut kawasan Hutan Ulayat terhadap kesatuan Masyarakat Hukum Adat, adalah: kesatuan masyarakat hukum adat dengan perusahaan. kesatuan masyarakat hukum adat dengan Pemerintah. 


\section{Jurnal Cakrawala Hukum I Volume 9 No. 1 Juni 2018}

ISSN PRINT 2356-4962 ISSN ONINE 2598-6538

Tak terkecuali yang terjadi di Weda, Kabupaten Halmahera Tengah, Provinsi Maluku Utara yang tak terbantahkan menjadi daerah yang kaya akan sumber daya alam. Hal ini menjadinya sebagai salah satu potensi yang marak diminati karena di dalam perut buminya mengandung Nikel, Minyak Bumi, Emas, Batubara, Pasir Besi, Asbas, dan lain-lain. Beberapa perusahaan lokal bekerja sama dengan pihak asing melakukan eksplorasi besar-besaran dan menyerap tenaga kerja yang cukup banyak. Salah satunya adalah PT. Weda Bay Nikel (lebih lanhut disingkat PT. WBN). PT. WBN, merupakan perusahan patungan beberapa pihak. Strand Minerals dimiliki secara gabungan oleh Eramet SA Perancis France dan Mitsubishi Corporation Jepang. Strand Minerals memiliki 90\% dari PT. WBN, dengan sisa 10\% dimiliki oleh PT Antam (10\%). Sebesar 65\% dari PT Antam dimiliki oleh Pemerintah Indonesia.

Perusahan PT. WBN mengajukan perijinan untuk melakukan kegiatan pertambangan dan pengolahan bijih nikel dan kobalt dengan proses hidrometalurgi di Kabupaten Halmahera Tengah dan Kabupaten Halmahera Timur, Provinsi Maluku Utara. PT. WBN merupakan pemegang Kontrak Karya Generasi Ketujuh (KK) berdasarkan Keputusan Presiden Republik Indonesia No.B.53/PRES/ 1/1998 tanggal 19 Januari 1998 untuk kegiatan pertambangan dan pengolahan bijih nikel dengan luas semula 120.500 ha dan setelah melalui penciutan terakhir menjadi 54.874 hektar. Luas konsesi PT. WBN terdapat di dalamnya tiga pemukiman penduduk, antara lain Desa Gemaf, Desa Lelilef Sawai dan Desa Lelilef Woebulen yang merupakan Suku Sawai ditambah dengan Kelompok Suku Tobelo Dalam (Togutil) di Ake Jira sebanyak 9 Kepala Keluarga (KK) yang disebut kelompok Yoram.

Proyek PT. WBN dibiayai oleh Multilateral Investment Guarantee Agency (MIGA). Selain itu juga masuk dalam Skema Masterplan Percepatan dan Perluasan Pembangunan Ekonomi Indonesia (MP3EI) dengan Nilai Investasi 83 Triliun Rupiah.
PT. WBN telah melakukan eksplorasi awal untuk pengembangan nikel laterit secara ekonomis di daerah Halmahera dimulai tahun 1996. Program eksplorasi dan pengembangan sumber daya alam skala kecil dimulai awal 1997 dan masih terus diperluas hingga saat ini.

Di Halmahera Tengah dan Halmahera Timur, Provinsi Maluku Utara (Malut), Sekitar 35.155 hektar wilayah konsesi PT. WBN berada di hutan lindung dalam wilayah Masyarakat Hukum Adat Sawai. Hal ini dilihat dari wilayah konsesi pertambangan yang sudah masuk ke perkampungan Masyarakat Hukum Adat Sawai. Inilah yang mengakibatkan konflik agraria tak terhindarkan. Sejak awal masuk, perusahaan ini sudah berkonflik dengan Masyarakat Hukum Adat Sawai dan Tobelo Dalam.

Konflik lahan antara perusahaan dengan masyarakat hukum adat juga terjadi di beberapa desa, seperti Desa Gemaf, Kobe, Sagea, dan Lelilef. Masuknya Perusahaan tambang mengakibatkan terancamnya hak-hak masyarakat hukum adat. Terancamnya Hak Ulayat masyarakat hukum adat Weda atau secara historis berasal dari Suku Sawai, karena desa-desa masyarakat masuk dalam konsesi wilayah tambang PT. WBN. Wilayah adat masyarakat pun dikuasai perusahaan. Tak hanya perampasan lahan, masyarakat pun terancam di relokasi karena kampungnya masuk dalam konsesi perusahaan.

Dalam pemanfaatan hutan ulayat masyarakat sendiri Masyarakat Hukum Adat juga sering mendapat intimidasi dan kriminalisasi oleh pihak perusahan tambang yang menggunakan aparat untuk menjaga daerah konsesi tambang masyarakat. Bahkan untuk menjaga kawasan konsesi perusah- an, pihak PT. WBN telah membangun pagar kawat duri untuk mencegah aktivitas dari masyarakat hukum adat tersebut.

Dalam Pasal 67 ayat (1) Undang-Undang Republik Indonesia Nomor 41 Tahun 1999 Tentang Kehutanan dinyatakan: Masyarakat hukum adat 


\section{Perlindungan Hutan Ulayat Masyarakat Hukum Adat Sawai dari Kegiatan Usaha Pertambangan}

Olvin Hady

sepanjang menurut kenyataannya masih ada dan diakui keberadaannya berhak: melakukan pemungutan hasil hutan untuk pemenuhan kebutuhan hidup sehari-hari masyarakat adat yang bersangkutan; melakukan kegiatan pengelolaan hutan berdasarkan hukum adat yang berlaku dan tidak bertentangan dengan undang-undang; dan mendapatkan pemberdayaan dalam rangka meningkatkan kesejahteraannya.

Berdasarkan Keputusan Presiden Nomor 41 Tahun 2004 tentang perijinan dibidang pertambangan yang berada di kawasan hutan, PT WBN merupakan salah satu dari 13 pemegang Kontrak Karya (KK) yang mendapat izin untuk melakukan kegiatan didalam kawasan hutan. Kawasan hutan yang dikuasai antara lain, hutan lindung seluas 16.004 ha, hutan produksi terbatas seluas 456 ha, hutan produksi tetap seluas 18.530 ha. Selain itu juga ada Areal Penggunaan Lain (APL) yang kebanyakan adalah perkebunan dan pemukiman masyarakat masuk di dalam wilayah konsesi PT. WBN.

Proses pembebasan lahan milik Masyarakat Hukum Adat Sawai diwarnai dengan intimidasi dan kriminalisasi bagi masyarakat yang tidak mau melepas lahannya.

Pembuatan kontrak karya 1996 antara Perusahaan dan pemerintah tidak melibatkan warga terdampak. Contohnya Suku Tobelo Dalam yang masih hidup dari alam. Perusahaan langsung masuk tanpa pembicaraan atau ada kesepakatan dengan warga, karena merasa berbekal izin pemerintah. Masyarakat diberitahukan ketika kesepakatan perusahan dengan pemerintah sudah selesai. Padahal Masyarakat Hukum Adat Sawai yang terkena dampak PT. WBN bisa dikatakan memiliki hak lahan sesuai dengan adat seperti yang digambarkan pada Standar Kinerja International Finance corporation (IFC), yang menyatakan bahwa:

"Masyarakat hukum adat umumnya terikat dengan lahan dan berhubungan dengan sum- ber daya alam. Seringkali, lahan ini dimiliki secara tradisional atau di bawah penggunaan adat. Walaupun Masyarakat hukum adat tidak memiliki hak milik legal atas lahan ini seperti yang didefinisikan oleh hukum nasional, cara masyarakat menggunakan lahan, termasuk penggunaan musiman atau berdasarkan siklus, untuk penghidupan masyarakat, atau budaya, upacara dan tujuan spiritual yang mendefinisi- kan identitas dan masyarakat, seringkali bisa menjadi bukti dan pendokumentasian yangkuat."

Tahun 1998 sejak izin perusahan ini keluar, perusahan langsung melakukankegiatan tahap demi tahap. Warga tidak pernah mendapat informasi seperti apa nanti perusahan tersebut. Konsultasi sama sekali tidak pernah dilakukan. Pihak perusahaan hanya berpatokan pada surat izin yang diberikan negara untuk melakukan kegiatan pertambangan. Proses perjalanan waktu nanti pada tahun 2008 dalam pembahasan Analisis Dampak Lingkungan Hidup (lebih lanjut disingkat ANDAL), baru warga tahu kalau wilayah pemukiman dan perkebunan masyarakat masuk dalam konsesi tambang sebagaimana terdapat dalam peta konsesi. Fakta ini menimbulkan kekhawatiran dari warga karena masyarakat berada di wilayah yang masuk kategori ring 1. Masyarakat tidak mendapat informasi seperti dampak yang akan dirasakan dikemudian hari. Dalam laporan Multilateral Investment Guarantee Agency (lebih lanjut disingkat MIGA), bahwa akan terjadi akuisisi tanah yang menyebabkan masyarakat berpindah mata pencahariannya.

Seharusnya dalam melakukan kegiatan usaha pertambangan, perusahaan pertambangan mendapat persetujuan dari masyarakat hukum adat setempat. Karena hutan tersebut adalah hutan yang merupakan hutan ulayat dari masyarakat hukum adat setempat dan juga mayoritas masyarakat hukum adat menghidupi diri masyarakat dengan 
cara menggunakan bagian dalam hutan untuk tujuan budidaya dan untuk memenuhi kebutuhan sehari-hari masyarakat. Budidaya, penduduk hanya perlu membuka sedikit wilayah hutan, atau tidak sama sekali, karena banyak tanamantanaman yang dibudidayakan dapat tumbuh diantara perpohonan.

Hal ini juga diperkuat dengan keputusan Mahkamah Konstitusi Nomor 35/PUU-IX/2012 yang menyatakan bahwa Hutan Ulayat yang semula menjadi Hutan Negara sekarang menjadi bagian dari Hutan Hak yang mana Hutan Hak adalah hutan yang berada di kawasan Masyarakat Hukum Adat.

Dalam kegiatan pembangunan yang berhubungan dengan sumber daya alam milik masyarakat hukum adat harus mendapatkan persetujuan dari masyarakat adat itu sendiri. Dalam menentukan nasib keadatan masyarakat, masyarakat hukum adat mempunyai haknya sendiri. Menentukan hak ulayat, masyrakat hukum adat dibantu oleh Aliansi Masyarakat Adat Maluku juga mengajukan Rancangan Peraturan Daerah untuk menetukan wilayah adat masyarakat. Namun hal ini ditolak oleh Bupati Halmahera Tengah dengan alasan lebih mengutamakan pembangunan nasional. Padahal, jauh sebelum kemerdekaan Indonesia, hutan-hutan ulayat itu sudah dikelolah oleh masyarakat hukum adat setempat.

\section{Metode}

Metode penelitian adalah suatu usaha untuk menemukan, mengembangkan dan menguji kebenaran suatu ilmu pengetahuan dilakukan dengan menggunakan metode ilmiah (Hadi, 1979). Jenis penelitian yang digunakan dalam penelitian ini adalah yuridis empiris yaitu bahwa dalam menganalisis permasalahan dilakukan dengan cara memadukan bahan-bahan hukum (yang merupakan data sekunder) dengan data primer yang diperoleh di lapangan yaitu tentang perlindungan hutan ulayat Masyarakat Hukum Adat Sawai Kabupaten
Halmahera Tengah, Provinsi Maluku Utara dari kegiatan usaha pertambangan PT. Weda Bay Nickel (Soemitro, 1990).

Pendekatan yang diguanakan dalam penelitian hukum ini adalah pendekatan yuridis-sosiologis, yaitu suatu pendekatan masalah dengan mengkaji peraturan yang berlaku dibandingkan dengan pelaksanaan ketentuan ketentuan yang ada pada lapangan. Semua data akan dianalisis dengan menggunakan metode deskriptif kualitatif, yaitu tata cara penelitian yang menghasilkan data deskriptif, yaitu apa yang dinyatakan responden secara responden secara tertulis maupun lisan dan perilaku nyata (Soekanto, 1986). Menguraikan dan menghubungkan semua data yang telah terkumpul dengan sedemikian rupa lalu mendeskripsikan data-data yang diperoleh dilapangan dan kemidian terhadap data-data tersebut dilakukan analisa.

Populasi dan Sampel yang menjadi populasi dalam penelitian ini adalah masyarakat hukum adat Sawai, Kabupaten Halmahera Tengah, Provinsi Maluku Utara. Sampel yang menjadi responden dalam penelitian ini adalah yaitu kepala desa, ketua Aliansi Masyarakat Adat Nusantara Maluku Utara, Polisi Resort Kabupaten Halmahera Tengah, Provinsi Maluku Utara, Dinas Kehutanan Provinsi Maluku Utara, Dinas Pertambangan Mineral dan Batu bara Provinsi Maluku Utara, Wahana Lingkungan Hidup Provinsi Maluku Utara beserta para pihak yang terkena dampak dari usaha tambang PT. Weda Bay Nickel.

\section{Pembahasan}

\subsection{Bentuk Perlawanan Masyarakat Hukum Adat Sawai untuk Melindungi Hutan Ulayat Masyarakat dari Kegiatan Usaha Pertambangan PT. Weda Bay Nickel.}

Kawasan hutan menjadi salah satu wilayah yang pemanfaatannya sudah dilakukan oleh Masyarakat Hukum Adat Sawai secara turuntemurun dan menjadikan Hutan sebagai salah satu Hak Ulayat Masyarakat. Namun sejak masuknya 


\section{Perlindungan Hutan Ulayat Masyarakat Hukum Adat Sawai dari Kegiatan Usaha Pertambangan}

Olvin Hady

Perusahaan PT. WBN, Masayarat kini harus rela melepas lahan masyarakat untuk dijadikan wilayah konsesi dari usaha pertambangan PT. WBN. Salah satunya adalah wilayah Hutan Ulayat yang diklaim oleh Pihak perusahaan sebagai Hutan Negara sehingga Masyarakat setempat tidak mempunyai hak terhadap hutan yang sudah masyarakat manfaatkan secara turun-temurun tersebut (Marshall dkk., 2013).

Proses pelepasan lahan oleh masyarakat Hukum Adat Sawai diwarnai oleh intimidasi dan kriminalisasi oleh aparat yang dipakai oleh pihak perusahaan. Hal ini mengakibatkan sebagian besar masyarakat merasa takut dan rela melepas lahan masyarakat dengan harga murah. Mayoritas dari keluarga masyarakat Hukum Adat Sawai telah menerima kompensasi dan meminta kesempatan kerja dan program tanggung jawab sosial perusahaan dari PT. WBN. Hal ini didukung dengan disebarluaskannya para pendukung proyek di tingkat Daerah, Provinsi dan Pusat dan menjadi faktor pendorong penduduk untuk menandatangani kesepakatan dengan PT WBN dan mendukung proyek (Marshall dkk., 2013).

Meski sebagian keluarga telah menandatangani kesepakatan, tetapi masih ada ketegangan antara perusahaan dan masyarakat, yaitu sejumlah kecil keluarga di setiap desa tetap bertahan dari tekanan untuk menerima kompensasi yang ditawarkan. Masyarakat menyatakan kalau masyarakat tidak tahu bagaimana masyarakat akan bertahan tanpa akses ke lahan budidaya.

Masyarakat khawatir tidak akan cukup lowongan kerja di PT. WBN, khawatir dengan apa yang akan terjadi ketika pertambangan ditutup, dan enggan mengubah cara hidup. Keluarga-keluarga ini, dikenal sebagai kelompok 50,000, telah menuntut jumlah kompensasi yang lebih tinggi (Rp. 50,000 per meter persegi) (Marshall dkk., 2013). Masyarakat telah mencari dukungan dari organisasi lokal seperti layanan legal masyarakat (LBH ProJusticia), organisasi lingkungan hidup (Walhi) dan organisasi hak-hak masyarakat adat (AMAN), serta melobi politisi di tingkat provinsi yang bersimpati. Sayangnya keterpencilan masyarakat menjadi penghalang dalam memperoleh lebih banyak dukungan. Dalam kondisi minoritas yang sedemikian rupa, keluarga-keluarga ini mengekspresikan perasaan putus asa dan tidak berdaya tentang kemungkinan masyarakat bisa melakukan negosiasi yang beritikad baik dengan pihak perusahaan.

PT. WBN juga dalam melakukan pendekatan memakai cara yang tidak tepat. Misalnya, perusahaan sering mendatangkan pemimpin agama untuk mempengaruhi keluarga yang tidak mau bekerja sama, dan memanfaatkan pemahaman jaringan kekerabatan dalam masyarakat untuk membuat anggota keluarga saling mempengaruhi. Lebih jauh lagi, PT. WBN hanya memilih pejabat desa tertentu untuk diajak bernegosiasi atas dasar kesediaan untuk menerima dan mempromosikan kompensasi, bukan karena kedudukan masyarakat di masyarakat. Bahkan sebagian masyarakat yang menerima kompensasi dikarenakan takut akan disalahkan atas pindahnya perusahaan, infrastruktur yang telah dibangun dan kesempatan kerja dari desa masyarakat (Marshall dkk., 2013).

Proses penawaran kompensasi jauh dari 'bebas'. Setelah negosiasi dengan Kepala Desa Lelilef Sawai, kesepakatan kompensasi sepihak tersebut ditawarkan pada masyarakat pemilik lahan dengan dasar 'lebih baik ambil daripada tidak dapat apa-apa', tanpa ada kesempatan negosiasi lebih lanjut atau perbaikan kesepakatan. Tidak ada kesempatan untuk negosiasi bebas. Secara terang-terangan perusahaan telah menolak ide untuk bernegosiasi langsung dengan orang desa setelah gagalnya negosiasi pertama. Ini juga merupakan pelanggaran hukum kontrak Indonesia. Pasal 1338 Kitab Undang-Undang Hukum Perdatamenyatakan bahwa:

"Semua persetujuan yang dibuat sesuai dengan undang-undang berlaku sebagai undang-undang bagi masyarakat yang membuatnya. Persetujuan itu tidak dapat ditarikkembaliselain dengankesepakatan 
kedua belah pihak, atau karena alas an-alasan yang ditentukan oleh undang-undang. Persetujuan harus dilaksanakan dengan itikad baik."

Dalam pasal ini menyatakan bahwa semua persetujuan harus dilakukan dengan itikad baik tanpa adanya paksaan ataupun intimidasi dari siapapun. Rasa ketikadilan inilah yang memicu perlawanan Masyarakat Hukum Adat Sawai terjadi pada tahun 2011, yaitu puluhan warga masyarakat yang menamakan dirinya Aliansi Peduli Masyarakat Lingkar Tambang (APMLT) melakukan aksi unjuk rasa di depan PT. WBN Desa Lelilef, Tanjung Ulie. Aksi unjuk rasa ini dilakukan karena selama beroperasi PT. WBN hanya mengambil hasil dan kekayaan alam tanpa mempedulikan masyarakat yang berada disekitar lokasi tambang. Perusahaan pertambangan yang merupakan perpanjangan tangan Eramet Perancis tersebut dianggap menelantarkan anak negeri yang bekerja pada perusahaan tersebut. Hasil dari unjuk rasa ini mengakibatkan terjadinya pembakaran terhadap speedboat dan mobil dinas milik PT. WBN yang dilakukan oleh Masyarakat Hukum Adat Sawai.

Aksi perlawanan yang dilakukan oleh Masyarakat Hukum Adat Sawai ini bertentangan dengan Hukum Nasional karena menurut Pasal 406 ayat

(1) Kitab Undang-Undang Hukum Pidana (KUHP), yang menyatakan bahwa:

"Barang siapa dengan sengaja dan melawan hukum menghancurkan, merusakkan, membikin tak dapat dipakai atau menghilangkan barang sesuatu yang seluruhnya atau sebagian milik orang lain, diancam dengan pidana penjara paling lama dua tahun delapan bulan atau pidana denda paling banyak empat ribu lima ratus rupiah."

Menurut Pasal 2 ayat (1) Undang-Undang Darurat No. 12 Tahun 1951 tentang Mengubah "Ordonnantietijdelijke Bijzondere Strafbepalingen" (Stbl. 1948 Nomor 17) dan UU Republik Indonesia
Dahulu Nomor 8 Tahun 1948 (“UU Drt. No. 12/ 1951") yang menyatakan sebagai berikut:

"Barang siapa yang tanpa hak memasukkan ke Indonesia, membuat, menerima, mencoba memperolehnya, menyerahkan atau mencoba menyerahkan, menguasai, membawa, mempunyai persediaan padanya atau mempunyai dalam miliknya, menyimpan, mengangkut, menyembunyikan, mempergunakan atau mengeluarkan dari Indonesia sesuatu senjata pemukul, senjata penikam, atau senjata penusuk (slag-, steek-, of stootwapen), dihukum dengan hukumanpenjarasetinggi-tingginyasepuluhtahun."

Tahun 2013 Masyarakat Hukum Adat Sawai memasang plang di wilayah adat masyarakat. Tulisan dalam plang itu menyampaikan kepada pihak luar bahwa ada pemilik wilayah adat yang harus dihormati. Pemasangan plang oleh Masya- rakat Hukum Adat Sawai untuk melindungi Hutan Ulayat masyarakat sesuai dengan keputusan Mahkamah Konstitusi Nomor 35/PUU-IX/2012 yang mana menyatakan bahwa Hutan Ulayat yang semula menjadi Hutan Negara sekarang menjadi bagian dari Hutan Hak yang mana Hutan Hak adalah hutan yang berada di kawasan Masyarakat Hukum Adat.

Dilihat dari berbagai bentuk perlawanan Masyarakat Hukum Adat Sawai merupakan perlawanan terbuka. Menurut Teori Perlawanan yang dikemukakan oleh James Scoot Scott (Zainuddin dkk, 2000).

\subsection{Upaya Penyelesaian Sengketa Antara Masyarakat Hukum Adat Sawai Dengan PT. Weda Bay Nickel Sebagai Bentuk Perlindungan Hukum dan Keadilan bagi Masyarakat Hukum Adat Sawai.}

Bentuk suatu penyelesaian sengketa merupakan serangkaian aktivitas yang dilakukan oleh para pihak yang bersengketa dengan menggunakan strategi untuk menyelesaikan sengketa. Menurut Nader dan Todd dalam bukunya Sulastriyono 
para pihak dapat mengembangkan beberapa strategi atau alternatif dalam menyelesaikan sengketa seperti (Sulastriyono, 1997):

"Lumping it atau membiarkan saja kasus itu berlalu dan mengangap tidak perlu diperpanjang; Avoidance atau mengelak yaitu para pihak yang merasa dirugikan memilih untuk tidak berhubungan lagi dengan pihak yang merugikan; Coercion atau paksaan yaitu satu pihak memaksakan pemecahan pada pihak lain, misalnya debt collector; Negotiation atau negosiasi yaitu dua pihak berhadapan merupakan cara pengambil keputusan; Mediation atau mediasi adalah campur tangan dari pihak ketiga untuk menyelesaikan sengketa tanpa memperdulikan bahwa kedua belah pihak yang bersengketa meminta bantuan atau tidak. Orang yang bertindak sebagai mediator seperti Kepala Desa/Camat, Kepala Pemerintah dan Hakim dan sebagainya; Arbitration atau arbiterasi yaitu jika kedua belah pihak ketiga yakni arbitrator/arbiter untuk menyelesaikan sengketa dan sejak semula sepakat atau menerima keputusan apapun dari arbitratos tersebut; Adjudication atau pengajuan sengketa ke pengadilan yaitu adanya campur tangan dari pihak ketiga (pengadilan) untuk menyelesaikan sengketa dan hasilnya ditaati oleh para pihak yang bersengketa."

Penyelesaian sengketa menurut Husen Alting, dapat dilakukan beberapa alternatif, seperti memberikan penyadaran terhadap pihak penguasa (perusahaan dan pemerintah) terhadap tindakan dan ketidakadilan yang telah masyarakat lakukan, sekaligus memberikan penguatan terhadap Masyarakat Hukum Adat Sawai akan hak-hak masyarakat yang perlu dilindungi. Cara lain yang dapat ditempuh adalah melalui jalur litigasi maupun nonlitigasi.

Upaya litigasi tidak dilakukan oleh masyarakat dengan pertimbangan, bahwa proses per- adilan sering membutuhkan banyak waktu, hal mana kemudian dapat menjadi kontar produktif bagi masyarakat akibat rasa frustasi dan pada akhirnya menghancurkan perjuangan. Selain itu badan peradilan cenderung berpihak kepada para penguasa yang memiliki modal yang cenderung dapat mengalahkan kepentingan masyarakat. Bagi Masyarakat Hukum Adat Sawai, pilihan terbaik adalah melalui jalur non-litigasi. Berbagai upaya dialog, musyawarah, negoisiasi dan bahkan unjuk rasa terlah dilakukan. Berbagai pihak telah diminta dukungan untuk bersama-sama membantu dan mendukung perjuangan Masyarakat Hukum Adat Sawai.

Upaya non-litigasi yang dilakukan, penciptaan opini merupakan salah satu bentuk yang cukup efektif dalam membantu perjuangan Masyarakat Hukum Adat Sawai. Masyarakat umum dan media lokal cukup berperan dalam memberikan informasi tetang ketidakberdayaan Masyarak Hukum Adat dalam menghadapi kesewenang-wenangan perusahaan. Pembntukan opini publik bertujuan untuk mempengaruhi pihak lain yang antipati menjadi simpati yang berlanjut pada empati. Dengan adanya empati yang diberikan maka Masyarakat Hukum Adat mendapat dukungan luas dari berbagai elemen masyarakat baik ditingkat lokal maupun nasional.

Upaya penyelesaian sengketa pembebasan lahan di Halmahera Tengah dilakukan dengan cara mediasi dan negosiasi yang telah difasilitasi penyelesaian melalui berbagai lembaga seperti Dewan Perwakilan Daerah (DPD), Wahana Lingkungan Hidup dan pertemuan dengan Komnas HAM pada 15 April 2012 di Jakarta. Namun dalam pertemuan itu tidak mengasilkan jalan tengah untuk menyelesaikan permasalahan antara Masyarakat Hukum Adat Sawai dengan PT. WBN. Hal ini terkait dengan penetapan harga tanah didasarkan pada keputusan bupati, padahal keputusan bupati tersebut bukan diperuntukan untuk pembebasan lahan dalam rangka penanaman modal, namun lebih pada standar harga ganti rugi untuk kegiatan 


\section{Jurnal Cakrawala Hukum I Volume 9 No. 1 Juni 2018}

ISSN PRINT 2356-4962 ISSN ONINE 2598-6538

pembangunan pemerintah. Pemerintah Daerah, pada situasi ini tidak dapat berbuat banyak bahkan cenderung berpihak kepada perusahaan.

Pilihan penyelesaian sengketa yang dilakukan oleh Masayarakat Hukum Adat Sawai untuk mendapat jaminan perlindungan hak atas sumber daya alam, sejalan dengan teori yang dikemukakan oleh Nader dan Todd, yakni melalui mediasi (mediation), negosiasi (negotiation), dan bahkan paksaan (coercion) oleh Masyarakat Hukum Adat Sawai. Pertimbangan ini didasarkan dengan pola penguasaan tanah yang dimiliki tidak akan berarti, bila dihadapkan pada penyelesaian melalui proses hukum formal.

Pilihan hukum penyelesaian sengketa oleh Masyarakat Hukum Adat Sawai, sejalan dengan pendapat Moore bahwa setiap bentuk masyarakat di mana pun dan kapan pun pada dasarnya mempunyai kemampuan untuk menciptakan normanorma dan mekanisme-mekanisme serta membangun isntitusi-institusi tertentu, untuk menyelesaikan setiap konflik yang timbul dalam masyarakat. (Alting, 2010).

Keberpihakan Pemerintah Daerah juga menyulitkan Masyarakat Hukum Adat Sawai untuk mendapat pengakuan terhadap hak tradisionalnya. Belum adanya pengakuan ini mengakibatkan hak Masyrakat Hukum Adat Sawai terhadap Hutan Ulayatnya tidak diakui karena dianggap sebagai Hutan Negara. Padahal Masyarakat Hukum Adat sawai umumnya terikat dengan lahan dan berhubungan dengan sumber daya alam. Seringkali, lahan ini dimiliki secara tradisional atau di bawah penggunaan adat. Walaupun Masyarakat Hukum Adat sawai tidak memiliki hak milik legal atas lahan ini seperti yang didefinisikan oleh hukum nasional, cara masyarakat menggunakan lahan, termasuk penggunaan musiman atau berdasarkan siklus, untuk penghidupan masyarakat, atau budaya, upacara dan tujuan spiritual yang mendefinisikan identitas dan masyarakat, seringkali bisa menjadi bukti dan pendokumentasian yang kuat.
Ditambah lagi dengan adanya keputusan Mahkamah Konstitusi Nomor 35/PUU-IX/2012 yang mana menyatakan bahwa Hutan Ulayat yang semula menjadi Hutan Negara sekarang menjadi bagian dari Hutan Hak yang mana Hutan Hak adalah hutan yang berada di kawasan Masyarakat Hukum Adat.

Berkaitan dengan perlindungan hukum yang dilakukan oleh pemerintah, Philipus M. Hadjon, membedakan menjadi dua macam, yakni perlindungan hukum secara prevemtif, dan perlindungan hukum secara represif.

Perlindungan hukum secara preventif, rakyat diberi kesempatan untuk mengajukan keberatan (inspraak) atau pendapatnya sebelum suatu keputusan pemerintah diformulasikan dalam bentuk yang definitive. Perlindungan hukum preventif bertujuan untuk mencegah terjadinya sengketa. Perlindungan hukum preventif sangat besar perannya bagi tindakan pemerintah yang didasarkan pada kebebasan bertindak karena dengan perlindungan hukum tersebut pemerintah didorong untuk bersikap hati-hati dalam melakukan pengambilan keputusan. Sedangkan perlindungan hukum secara represif adalah upaya perlindungan yang dilakukan melalui badan peradilan, baik peradilan umum maupun peradilan administrasi Negara. Perlindungan hukum secara represif bertujuan untuk menyelesaikan sengketa (Hadjon, 1987).

Landasan pijak perlindungan hukum bagi rakyat Indonesia ialah pancasila dan UUD 1945, karena Pancasila merupakan dasar idiologi dan dasar falsafah bangsa Indonesia yang menjunjung tinggi nilai-nilai kemanusiaan dengan menempatkan hukum sebagai panglima, bukan kekuasaan sebagai penentu. Pernghormatan terhadap Hak Asasi Manusia, dan pemosisian Indonesia sebagai Negara hukum (rechstaat) akan menimbulkan konsekuensi hukum yang harus ditaati dan dilaksanakan oleh pemerintah sebagai penyelengara Negara. Hal ini sesuai dengan pendapat Philipus M. Hudjon bahwa dalam merumuskan prinsip perlindungan hukum 


\section{Perlindungan Hutan Ulayat Masyarakat Hukum Adat Sawai dari Kegiatan Usaha Pertambangan}

Olvin Hady

bagi rakyat (di indonesia) harus didasarkan pada prinsip pengakuan dan perlindungan harkat dan martabat manusia yang bersumber pada Pancasila dan prinsip Negara hukum berdasarkan Pancasila (Alting, 2010).

Berkaitan dengan hak Masyarakat Hukum Adat atas sumber daya alam, dapat dipahami bahwa Negara memikul kewajiban, atau dengan kata lain perlu dilakukan pembatasan terhadap tindaktanduk Negara dengan organ-organnya, serta meletakkan kewajiban Negara terhadap warganya, sehingga prinsip yang terkandung dalam Hak Asasi Manusia adalah tuntutan (claim) akan hak warga Negara dan kewajiban yang harus dilakukan oleh Negara. Phillipus M. Hudjon menegaskan bahwa sebagai makhluk sosial, individu warga Negara tidak hanya menuntut haknya terhadap Negara, tetapi menyadari apa kewajibannya terhadap Negara yang telah dibangun atas kehendak bersama sebagai dorongan kodrat untuk hidup bermasyarakat.

Jadi untuk mengindari terjadi kesewenangwenangan, seharusnya dapat dibuat peraturan mengenai kekhususan Masyarakat Hukum Adat Sawai. Karena pada prinsipnya perlindungan hukum harus melaui penghormatan harkat dan martabat yang harus diarahkan pada perlindungan terhadap hak sosial, hak ekonomi, dan hak kultural agar tercapainya suatu keadilan bagi Masyarakat Hukum Adat sawai. Hal mana keadilan menurut John Rawl dalam bukunya a theory of justice menjelaskan tentang teori sosial sebagai the difference principle dan the principle of fair equality of opportunity. Inti the difference principle, adalah bahwa perbedaan sosial dan ekonomi harus bisa diatur supaya memberikan manfaat yang sebesar-sebesarnya bagi masyarakat yang kurang beruntung.

\section{Simpulan}

Dari berbagai perlawanan Masyarakat Hukum Adat Sawai di atas, dapat disimpulkan bahwa ada yang bertentangan dengan Hukum Nasional dan ada juga yang sudah sesuai dengan Hukum Nasional.Permasalahan upaya penyelesaian sengketa pembebasan lahan antara Masyarakat Hukum Adat Sawai dengan PT. WBN di Halmahera Tengah belum maksimal. Meskipun telah difasilitasi melalui berbagai lembaga seperti Dewan Perwakilan Daerah (DPD), Wahana Lingkungan Hidup dan pertemuan dengan Komnas HAM pada 15 April 2012 di Jakarta. Namun dalam pertemuan itu tidak menghasilkan jalan tengah untuk menyelesaikan permasalahan antara Masyarakat Hukum Adat Sawai dengan PT. WBN.

\section{Daftar Pustaka}

Alting, Husen. 2010. Dinamika Hukum dalam Pengakuan dan Perlindungan Hak Masyarakat Hukum Adat Atas Tanah. Yogyakarta. LaksBang PRESSindo.

Hadjon, Philipus M. 1987. Perlindungan Hukum Bagi Rakyat Indonesia. Surabaya. Bina Ilmu.

Kitab Undang-Undang Hukum Perdata.

Kitab Undang-Undang Hukum Pidana.

Marshall, Shelley, dkk. 2013. Akses untuk Keadilan bagi Masyarakat yang Terkena Dampak Pertambangan PT Weda Bay Nickel. Laporan Sementara. Proyek Mekanisme Non-Yudisial Yang Mengatur Perilaku Perusahaan Terhadap Hak Asasi Manusia. Oktober 2013.

Murad, Rusmadi. 1991. Penyelesaian Sengketa Hukum Atas Tanah, Alumni. Bandung. Mandar Maju.

Peraturan Menteri Dalam Negeri Republik Indonesia Nomor 52 Tahun 2014 tentang Pedoman Pengakuan dan Perlindungan Masyarakat Hukum Adat.

Putusan Mahkamah Konstitusi Republik Indonesia Nomor: 35/PUU-X/2012.

Rawls, John. 1997. A Theory Of Justice. Cambridge Massachuset. Harvard University Press.

Scott, James C. 2000. Senjatanya Orang-Orang yang Kalah. terj. A. Rahman Zainuddin dkk. Jakarta. Yayasan Obor Indonesia. 


\section{Jurnal Cakrawala Hukum I Volume 9 No. 1 Juni 2018}

ISSN PRINT 2356-4962 ISSN ONINE 2598-6538

Soekanto, Soerjono, dkk. 2001. Penelitian Hukum Normatif. Jakarta. Raja Grafindo Persada.

Soekanto, Soerjono. 1986. Pengantar Penelitian Hukum. Jakarta. UI-Press.

Soemitro, Ronny Hanitijo. 1990. Metodologi Penelitian Hukum dan Jurimetri. Jakarta. Ghalia Persada.

Sumardjono, Maria S.W. 2005. Kebijakan Pertanahan, Antara Regulasi dan Implementasi. Jakarta. Kompas.

Tarrow, Power In Movement, Social Movement, Collective Action and Politics. Cornel University. Sidney.

Undang-Undang Darurat Republik Indonesia Nomor 12 Tahun 1951 tentang Mengubah "Ordonnantietijdelijke Bijzondere Strafbepalingen" (Stbl. 1948 Nomor 17) dan UU Republik Indonesia Dahulu Nomor 8 Tahun 1948 ("UU Drt. No. 12/1951")
Undang-Undang Dasar Negara Republik Indonesia Tahun 1945.

Undang-Undang Republik Indonesia Nomor 23 Tahun 2015 tentang Pemerintahan Daerah.

Undang-Undang Republik Indonesia Nomor 39 Tahun 1999 tentang Hak Asasi Manusia.

Undang-Undang Republik Indonesia Nomor 4 Tahun 2009 tentang Pertambangan Mineral dan Batu Bara.

Undang-Undang Republik Indonesia Nomor 41 Tahun 1999 tentang Kehutanan.

Undang-Undang Republik Indonesia Nomor 5 Tahun 1960 tentang Peraturan Dasar Pokok-Pokok Agraria. 